\title{
Pertanggung Jawaban Hukum oleh Seorang Dokter yang Melakukan Tindak Pidana Pemalsuan Surat Keterangan Dokter
}

\author{
Legal Liability by a Doctor Who Commits the Crime of \\ Falsifying Doctor's Certificate
}

\author{
Juli Shara Pasaribu*, Chistofe Daeli ,Koko Valensio Situmeang \& \\ Sonya Airini Batubara
}

Ilmu Hukum, Fakultas hukum, Universitas Prima Indonesia, Indonesia

Diterima: 07 September 2020; Direview: 05 Oktober 2020; Disetujui: 14 Oktober 2020 *Coresponding Email: julisharapasaribu@gmail.com

\begin{abstract}
Abstrak
Tujuan penelitian yang digunakan adalah untuk mengetahui pertanggungjawaban etika dan hukum seorang dokter yang melakukan tindak pidana pemalsuan surat keterangan dokter dan untuk mengetahui cara penanggulangan secara hukum tindak pidana yang dilakukan oleh seorang dokter dalam bidang hukum kesehatan. metode penelitian menggunakan yuridis normatif yaitu menggunakan penelitian secara perpustakaan dan sumber bahan hukum yang digunakan adalah data sekunder. Penelitian ini menggunakan teori pertanggungjawaban. Pemalsuan surat menerbitkan suatu hak yang dipergunakan sebagai keterangan palsu tentang ada atau tidaknya penyakit. Tindak Pidana yang sering terjadi adalah berkaitan dengan Pasal 263 KUHP (membuat surat palsu atau memalsukan surat) Pasal 266 KUHP bagi dokter yang melakukan pemalsuan surat dihukum dengan penjara paling lama empat (4) Tahun.Seorang dokter wajib memberikan surat keterangan dan pendapat yang telah diperiksa sendiri kebenarannya. Penanggulangan pemalsuan surat dilakukan melalui 2 upaya yaitu upaya penal dan upaya non penal yang dilakukan secara represif (penegakan hukum). Penanggulangan dapat dilakukan dengan pemberian penambahan pembekalan baik secara etik ataupun disiplin kepada setiap dokter.
\end{abstract}

Kata Kunci: Pemalsuan, Penanggulangan, Tindak Pidana

\begin{abstract}
The research objectives used were to determine the ethical and legal accountability of a doctor who commits a criminal act of doctor's certificate forgery and to find out how to legally handle a criminal act committed by a doctor in the field of health law. The research method uses normative juridical, namely using library research and the source of legal materials used is secondary data. This research uses the theory of responsibility. Letter forgery issues a right which is used as false information about the presence or absence of disease. Criminal acts that often occur are related to Article 263 of the Criminal Code (making forged letters or falsifying letters) Article 266 of the Criminal Code for a doctor who falsifies a letter sentenced to a maximum imprisonment of four (4) years. A doctor is required to provide a statement and opinion that has been examined itself the truth. Overcoming letter forgery is carried out through 2 efforts, namely penal measures and non-penal measures carried out repressively (law enforcement). Prevention can be done by providing additional provisioning both ethically and in discipline to each doctor Keywords: Counterfeiting, Prevention, Health Workers
\end{abstract}

How to Cite: Pasaribu, J.S., Situmeang, K.V., Daeli, C., \& Batubara, S.A., (2020). Pertanggung Jawaban Hukum Oleh Seorang Dokter Yang Melakukan Tindak Pidana Pemalsuan Surat Keterangan Dokter. Journal of Education, Humaniora and Social Sciences (JEHSS). 3(2): 434-441. 


\section{PENDAHULUAN}

Hukum selalu berkembang seiring berkembangnya masyarakat, Indonesia sebagai negara yang berkembang mempunyai beberapa kewajiban untuk melaksanakan yang disepakati oleh 1993 negara. Hukum indonesia sangat sering digunakan didalam kehidupan sehari-hari untuk menunjukkan pada sistem norma yang berlaku dan diberlakukan di Indonesia, hukum ini hukum positif dan hukum ini juga yang berlaku saat ini di Indonesia. Perkembangan hukum saat ini adalah kaca dari suatu perkembangan masyarakat (Hunt, 1978).

Pemalsuan adalah proses suatu pembuatan, meniru beradaptasi, benda, statistik, dan atau dokumen-dokumen (lihat dokumen palsu), yang dengan maksud untuk menipu. Kejahatan yang serupa dengan penipuan adalah kejahatan memperdaya hal apapun, dapat termasuk melalui penggunaan benda yang diperoleh melalui pemalsuan. Surat adalah lembaran kertas yang diatasnya terdapat tulisan kata, frasa dan kalimat yang terdiri dari huruf-huruf atau angka dalam bentuk apa pun yang dibuat dengan cara apa pun yang tulisan mana mengandung arti dan makna suatu pemikiran manusia (Jusiven, 2000).

Kebenaran ini atau makna tersebut harus mendapat perlindungan hukum yang dibentuknya tindak pidana pemalsuan surat ini ditujukan bagi perlindungan hukum terhadap suatu kepercayaan masyarakat terhadap kebenaran mengenai isi-isi surat tersebut. Tindak pidana pemalsuan surat terebut dibentuk untuk memberikan perlindungan hukum terhadap kepercayaan yang diberikan oleh umum (publica fides) pada surat analisis yuridis terhadap malpraktek yang dilakukan dokter (https://id.wikipedia.org/wiki/Pemalsuan diakses tanggal 27 september 2019).

Tindak pidana pemalsuan semakin hari semakin meningkat/ marak terjadi dan sangat cepat berkembang dimasyarakat. Hal in disebabkan tidak lepas dari berbagai aspek eperti aspek social, aspek lingkungan, dan aspek ekonomi. Dan pemalsuan ini sudah sangat sering dianggap perbuatan yang sering dijumpai di kalangan masyarakat dan hal ini juga dianggap sebagai kejahatan bertentangan terhadap suatu kepentingan umum karena dapat merugikan (Lasminar \& Isnaini, 2014).

Kerugian merupakan unsur yang paling penting dalam pemalsuan surat yang harus dibuktikan yang harus dibuktikan. Pemalsuan surat dianggap tidak terjadi. Hal ini diperlukan penafsiran atau interprestasi megenai kerugian yang berdampak terhadap masyarakat dan penegak hukum (Santosa, 2016).

Hukum pidana Belanda yang mengikuti Code Penal mengenai pemalsuan, yang memakai istilah faux en ecritures, maka pemalsuan hanya dapat dilakukan dalam surat-surat, yang diartikan sebagai tiap-tiap penciptaan pikiran yang dituliskan dalam perkataan yang dibuat dengan cara apapun, dan surat-surat yang dapat menjadi objek tidak semua jenis surat. Hukum di Indonesia dapat berkembang seiring dengan perkembangan yang berada di dalam masyarakat. Demikian juga permasalahan hukum yang hampir setiap hari kita jumpai dilingkungan kita sehari-hari baik itu permasalahan yang menimbulkan kerugian pada suatu individu, masyarakat, ataupun dalam Negara. Permasalahan yang cukup banyak terjadi di lingkungan masyarakat adalah kejahatan pemalsuan. Tindak pidana pemalsuan surat merupakan bentuk kejahatan pidana yang menarik perhatian mayarakat, karena pembuatan surat yang menimbulkan hak dan atau kewajiban pihak lain tanpa pemberitahuan pihak yang dirugikan (Bambang, 2016).

Pemalsuan merupakan salah satu bentuk perbuatan yang dianggap sebagai kejahatan yang bertentangan dengan kepentingan umum. Sebab dan akibat perbuatan itu menjadi perhatian dari berbagai pihak, dengan mengadakan penelitian-penelitian berdasarkan metode ilmiah agar dapat diperoleh suatu kepastian untuk menetapkan porsi dan klasifikasi dari kejahatan tersebut. Sangat banyak perbuatan hukum yang termasuk dalam kejahatan pemalsuan surat, pemalsuan tanda tangan ataupun cap atau stempel. Hal ini merupakan salah satu diantara suatu bentuk pemalsuan surat. Salah satu contoh masalah pemalsuan tanda tangan, ini adalah ini salah satu suatu bentuk kejahatan yang masih kurang dipahami oleh masyarakat yang termasuk di dalamnya para aparat penegak hukum. Dan masih banyak juga masyarakat yang menganggap hal 
Juli Shara Pasaribu, Chistofe Daeli,Koko Valensio Situmeang, , \& Sonya Airini Batubara, Pertanggung Jawaban Hukum oleh Seorang Dokter yang Melakukan Tindak Pidana Pemalsuan Surat Keterangan Dokter

ini sangat sepele mengenai pemalsuan surat ini, bahkan tidak tahu bahwa apabila mereka melakukannya dapat terancam hukuman pidana. Tindak Pidana yang sering terjadi adalah berkaitan dengan Pasal 263 KUHP (membuat surat palsu atau memalsukan surat) dan dalam Pasal 264 (memalsukan akta-akta otentik) dan Pasal 266 KUHP (menyuruh memasukkan keterangan palsu ke dalam suatu akta otentik).

Selain pemalsuan surat yang dibuat seseorang dokter yang seolah-olah mengatasnamakan surat terhadap pasien bukan mengatasnamakan nama yang sebenarnya pembuat dokter sendiri. Pemalsuan surat disebut juga dengn pemalsuan materil. Pemalsuan surat bukan terletak dari dari sisi surat tetapi pada nama orang, hal ini termasuk juga dengan tanda tangan. Sipembuat surat seperti pada nama orang yang sebenarnya didalam surat tersebut. Contohnya juli membuat surat seperi surat atau berasal dari koko. Karena nama beserta tanda tangan si koko dicantumkan dalam surat, tetapi sebenarnya yang membuat dan menandatanganunya sijuli sendiri dengan meniru tanda tangan sikoko. Dapat juga dengan tidak meniru tanda tangan si kiki tetapi membuat tanda tangan palsu seperti tanda tangan si koko (Aludin, 2008).

Hukum pidana belanda mengikuti code penal mengenai pemalsuan yang disebut dengan istilah faux en ecritures, yang berarti pemalsuan hanya dapat dilakukan dalam surat-surat yang diartikan sebagai tiap-tiap suatu penciptaan pikiran yang dituliskan dalam dalam perkataan yang dibuat dengan suatu cara apapun dalam surat-surat yang dapat menjadi sebuah objek dan tidak semua jenis surat ialah hanya empat macam saja (Chazawi, 2002):

1. Pemalsuan pada umumnya dalam bentuk pokok pemalsuan surat, ( pasal 263 KUHP)

2. Pemalsuan surat diperberat ( pasal 264 KUHP)

3. Menyuruh memasukkan keterangan palu kedalam suatu akta otentik ( pasal 266 KUHP)

4. Pemalsuan surat keterangan dokter (pasal 267-268)

5. Pemalsuan surat-surat tertentu (terdapat dalam pasal 269, 270, $271 \mathrm{KUHP}$ )

6. Pemalsuan keterangan pejabat tentang hak milik (paal 275 KUHP)

7. Menyimpan Bahan Atau Benda Untuk Melakukan Pemalsuan Surat (Pasal 275 KUHP).

\section{METODE PENELITIAN}

Jenis perpustakaan yang digunakan adalah penelitian secara yuridis normatif yaitu penelitian kepustakaan karena penelitian ini hanya bertujuan pada peraturan-peraturan tertulis sehingga penelitian ini sangat erat hubunganya dengan perpustakaan karena disebabkan dibutuhkannya data-data yang bersifat sekunder

Sifat penelitian yang digunakan adalah penelitian yang menggambarkan dan memaparkan mengenai topik atau judul serta permasalahan yang muncul dari topik terebut yang melalui studi kepustakaan yang terkait erat dengan materi tindak pidana pemalsuan surat.

Sumber bahan hukum yang dapat digunakan adalah data sekunder yaitu data yang diperoleh sumbernya telah ada sebelumnya atau perpustakaan dengan cara mengumpulkan data yang terdapat dalam peraturan perundang-undangan, buku-buku beserta makalah atau artikel yang berkaitan dengan masalah yang diteliti (Samidjo, 2012): a) Bahan hukum primer, meliputi: Undang-undang No 1 Tahun 1946 tentang hukum pidana dan Undang- undang No .4 Tahun 2011 Tentang Disiplin Profesional Dokter; b) Bahan hukum sekunder, yaitu bahan yang memberikan penjelasan terkait bahan hukum primer seperti buku-buku, kripsi beserta makalah yang terkait dalam penelitian ini.

\section{HASIL DAN PEMBAHASAN}

\section{Pertanggungjawaban Etika Dan Hukum Seorang Dokter Yang Melakukan Tindak Pidana Pemalsuan Surat Keterangan Dokter}

Dalam praktik kedokteran kadang beberapa orang menulis surat keterangan perihal seorang dokter pasien yang diperiksa dokter, adalah orang lain bukan dokter. Orang yang bukan dokter contohnya perawat/ juru rawat dan mantri yang perbantukan oleh dokter. Kadangkadang ada praktik dokter atau rumah sakit yang menyediakan atau menyiapkan blanko-blanko 
dalam bentuk tertentu yang pengisiannnya diserahkan kepada mantri atau pembantu dokter. Pemalsuan adalah Tindak pidana yang dibentuk untuk memberi perlindungan hukum terhadap kepercayaan yang diberikan kepada masyarakat umum (publica fides) pada surat (Simons, 1992). Pemalsuan ini juga merupakan tindak pidana yang mengandung palsu atau dipalsunya berita yang telah disampaikan secara verbal. Sebuah dokter yang membuat surat palsu atau sipembuat surat tidak dapat dibuktikan atau tidak ditemukan dapat dituntut semisalnya meninggal dunia (Syamyudi, 2004). Maka objek surat palsu atau surat yang dipalsukan diadili dan dipidana sementara sipembuat suratnya tidak diadili misalnya tidak ditemukan orangnya.

Tindak pidana pemalsuan pada umumnya bentuknya standar atau yang terdapat dalam pasal 263 ayat (1) yang sudah dibahas. Pemalsuan surat ini dalam pasal 264 merupakan lex specialis dari pemalsuan. Dan mengandung unsur-unsur yang sama yang dasar pemberatannya pidananya terletak pada jenis-jenis surat yang menurut sifatnya mengandung alasan pembenaran. Frasa/unsur seolah-olah menandakan bahwa surat yang digunakan itu merupakan bukan surat yag isinya benar dan tidak benarnya bisa disebabkan isinya palsuatau isinya dipalsu. Dan tidak benarnya isi surat yang digunakan harus dapat dibuktikan (https://www.hukumonline.com/klinik/detail/ulasan/lt5812fd6ae0ce3/pidana-bagi-dokteryang-membuat-surat-keterangan-sakit-palsu/ diakses tanggal 10 januari 2020). Tindak pidana membuat surat palsu atau memalsukan surat yang terdapat di dalam ayat (1). Pidana pada umumnya hendaknya dapat dijatuhkan hanya pada barangsiapa melakukan perbuatan yang dilarang dengan dikehendaki dan diketahui. Kesengajaan adalah sikap batin orang yang mengkehendaki dan sikap batin orang yang mengetahui tentang sesuatu. Apa yang dikehendaki adalah apa yang diketahui dan orang yang selalu menghendaki segala sesuatu yang sebelumnya diketahuinya. Pemalsuan juga diancam dengan pidana penjara yang paling lama delapan tahun, jika yang dilakukan terhadap sebagai berikut: a) Akta-akta autentik. Yang dimaksud dengan akta autentik adalah akta yang dibuat dalam suatu bentuk yang sudah ditentukan oleh undangundang dan hal ini dibuat dihadapan pegawai-pegawai pada umumnya yang berkuasa untuk itu dan tempat dimana dibuat akta tersebut. Dan hal ini bersifat perjanjian antara kedua belah pihak yang isinya berdasarkan kesepakatan kedua belah pihak yang berazas berkontrak; b) Surat hutang atau sertifikat hutang dari suatu negara atau bagian dari suatu lembaga; c) Tanda bukti yang dikeluarkan sebagai penganti surat-surat tersebut; d) Surat kredit atau surat yang diperuntukkan untuk diedarkan

Hal ini diancam dengan pidana yang sama dengan barang siapa sengaja yang memakai surat tersebut dalam ayat yang pertama yang didalamnya tidak sejati atau yang dipalsukan seolah-olah benar dan tidak dipalsu dan jika pemalsuan tersebut dapat menimbulkan kerugian bagi masyarakat. Dalam suatu rumusan pemalsuan surat yang terdapat di ayat (1) ada dua perbuatan yang terdapat dalam ayat ini yaitu membuat palsu dan memalsukan "bila dihubungkan dengan suatu objeknya dalam sebuah surat, perbuatan yang pertama biasanya dikategorikan dalam perbuatan membuat surat palsu. Surat palsu dapat juga diartikan dapat membuat sebuah surat yang sebelumnya tidak ada surat yang isi seluruhnya terdapat pada bagian-bagian yang tertentu tidak sesuai dengan yang sebenarnya atau pada bagian-bagian tertentu tidak sesuai dengan yang sebenarnya atau bertentanga dengan kebenaran atau palsu. Surat yang dihasilkan oleh perbuatan membuat surat palsu itu disebut surat palsu atau surat yag tidak asli. Unsur kualitas tertentu tindak pidana adalah unsur bagi kualitas pribadi apa atau kepada rumusan terhadap tindak pidana itu ditujukan (Chazawi, 2011). Tindak pidana pemalsuan surat pada umumnya adalah berupa pemalsuan surat dalam bentuk pokok atau bentuk standar yang terdapat dalam pasal 263, rumusanya adalah sebagai berikut;

Barangsiapa membuat surat palu atau memalsukan atau pembebasan utang atau yang diperuntukan sebagai alat bukti daripada sesuatu hal yang dimaksud untuk memakai atau menyuruh orang lain untuk memakai surat terebut seolah-olah isinya benar dan tidak palsu, pidana, jika pemakainya terebut dapat menimbulkan kerugian, karena pemalsuan surat, dengan pidana penjara paling lama 6 bulan 
Juli Shara Pasaribu, Chistofe Daeli,Koko Valensio Situmeang, , \& Sonya Airini Batubara, Pertanggung Jawaban Hukum oleh Seorang Dokter yang Melakukan Tindak Pidana Pemalsuan Surat Keterangan Dokter

Dipidana dengan yang sama, barang siapa dengan sengaja memakai surat palsu atau yang dipalsukan seolah-olah asli, jika pemakaian surat dapat menimbulkan kerugian

Sumber utama pidana adalah kitab undang-undang pidana (KUHP) yang terdiri dari tiga buku yaitu buku 1 mengatur peraturan-peraturan umum, buku II mengatur tentang kejahatan dan buku III mengatur tentang pelanggaran. Kejahatan pemalsuan . terdapat dua perbuatan ialah membuat palsu dan memalsu. Membuat surat palsu yaitu membuat surat yang isinya tidak benar (Chazawi dan Ferdinan, 2016). Suatu perbuatan pemalsuan dapat dihukum apabila sebagai berikut (Satoso, 2001): Pelaku mempunyai niat untuk mempergunakan sesuatu barang yang tidak benar dengan menggambarkan keadaan barang yang tidak benar itu seolah-olah benar atau mempergunakan sesuatu barang yang tidak asli seolah-olah suarat tersebut asli atau nyata , hingga orang lain percaya bahwa barang tersebut adalah benar dan asli dan karenanya orang lain terperdaya.

a. Terdapat Unsur niat/ bermaksud, hal ini dimaksud tidak perlu memperoleh unsu- unsur menguntungkan diri sendiri atau yang sebaliknya terhadap orang lain yang berbagai jenis perbuatan penipuan. Tetapi didalam perbuatan ini dapat menimbulkan suatu bahaya umum yang terkhusus didalam pemalsuan tulisan/ pemalsuan surat dan sebagainya.

Tanggungjawab mengandung arti keadaan cakap terhadap suatu beban kewajiban atas segala sesuatu akibat perbuatan, yang mana dari pengertian tanggungjawab tersebut harus memiliki bebeapa unsur: Kecakapan, Beban kewajiban, Perbuatan. Dan Dapat disimpulkan bahwa unsur kewajiban mengandung makna yang harus dilakukan, dan tidak boleh tidak dilakukan, jadi sifatnya harus ada atau keharusan. Fungsi etika dan hukum adalah menuntun dan menjelaskan nilai-nilai baik dan buruk serta larangan-larangan yang bias dilakukan atau tidak dilakukan akan menimbulkan ketidakadilan dan akan menimbulkan sanksi. Kehidupan Etika kedokteran merupakan seperangkat perilaku anggota profesi kedokteran dalam hubungannya dengan klien dan atau pasien, teman sejawat dan masyarakat umumnya serta merupakan bagian dari keseluruhan suatu proses pengambilan keputusan dan tindakan medis ditinjau dari segi norma-norma/nilai-nilai moral (Suharto, 2016). Dokter adalah pihak yang mempunyai keahlian di bidang kedokteran. Pada Kedududukan tersebut dokter merupakan seorang yang dianggap pakar dalam bidang kedokteran. Dokter adalah orang yang memiliki kewenangan dan izin sebagaimana mestinya untuk melakukan pelayanan kesehatan, khususnya memeriksa dan mengobati penyakit dan dilakukan menurut hukum dalam pelayanan kesehatan (Jayanti, 2009). Kode etik profei merupakan asas-asas moral dalam sebuah profesi yang disusun ecara sistematis. Subtansi kode etik profesi ini adalah kewajiban yang harus dilakukan oleh semua anggota profesi dalam menjalankan pelayanannya terhadap klien atau masyarakat. Kode etik profesi disusun oleh organisasi profei yang bersangkutan.

Ruang lingkup kewajiban bagi anggota profesi atau kode etik adalah: a) Kewajiban umum; b) Kewajiban terhadapa klien; c) Kewajiban terhadap teman sejawat; d) Kewajiban terhadap diri sendiri. Mengenai pemalsuan surat keterangan dokter terdapat di pasal 267 dan 268 KUHP. Surat Keterangan Dokter merupakan suatu surat atau tulisan dalam sebuah kertas yang dibuat oleh Dokter yang isinya menerangkan mengenai kondisi atau keadaan kesehatan maupun penyakit seorang pasien atau seseorang yang meminta surat dimaksud. Bila subjek hukum tindak pidana tindak pidana dalam rumusan yang secara khusus

didalam suatu surat keterangan dokter diharuskan memenuhi beberapa hal agar sebuah surat dapat disebut surat keterangan seorang dokter (Marpaung, 2011), sebagai berikut: a) Dokter Harus ada, yang dimaksud adalah seseorang yang telah definitif dinyatakan sebagai dokter; b) Harus ada pasien, yang dimaksud dengan seseorang yang akan dinyatakan kondisi atau keadaan kesehatannya tidak baik oleh Dokter; c) Harus ada surat yang didalamnya terdapat mengenai kondisi atau keadaan kesehatan seorang pasien. Dan didalam Surat tersebut harus ditandatangani oleh pembuatnya yang disebut dokter dan/atau adanya stempel Dokter atau Rumah Sakit.

Saat ini diindonesia sering terjadi kasus pemalsuan "surat keterangan palsu" yang dilakukan dokter di Republik ini. Misalnya mendengar kasus Eddy Tansil buronan nomor wahid di Indonesia, Surat keterangan dokter, semua kita tahu bahwa bentuknya sangat sederhana dan 
gampang sekali membuatnya. Dokter atau siapapun sangat gampang mengisi surat tersebut dengan kehendak tergantung kepentingannya dirinya sendiri. Dan sering kali menemukan lawan perkara dan tidak menghadiri persidangan dengan alasan sakit dengan melampirkan surat keterangan dokter yang menyatakan bahwa seseorang tersebut sakit. "Sakitnya" lawan perkara ini maka dia akan diijinkan oleh Hakim untuk absen sidang. Maka absennya sidang ini sering disalahgunakan untuk melakukan perbuatan-perbuatan yang merugikan pihak-pihak yang berperkara contohnya dalam menandatangankan barang-barang yang menjadi obyek perkara secara melawan hukum. Surat keterangan dokter menyatakan bahwa seorang lawan perkara sakit namun hari itu pula orang merusak obyek perkara. Seseorang dapat "absen waras" ketika seseorang dimaksud dihadapkan dimuka sidang sehingga berakibat orang tersebut tidak dapat di adili karena orang tersebut telah dinyatakan oleh dokter bahwa orang dimaksud sakit ingatan atau gila atau sakit jiwa akut atau lumpuh otak. Kemudian orang tersebut lepas dari segala tuntutan hukum (penjara). Mengingat surat keterangan dokter adalah sebuah akta otentik sehingga selama tidak ada yang membatalkan dan dinyatakan batal oleh Pengadilan, maka surat keterangan dokter akan selalu dianggap asli dan benar isinya.

Apabila ada orang yang bukan dokter membuat surat keterangan palsu seolah-olah dibuat oleh seorang dokter diterapkan dalam pasal 267 bahwa tindak pidana pemalsuan surat pada umumnya atau yang berbentuk standar dan bagi orang yang menggunakan dapat dipidana yang berdasarkan pasal 263 ayat (2). Dokter adalah sebagai pembuat surat dan dibebani pertanggungjawaban pidana dan jika orang terlibat dengan dokter sebagai penganjur dan pelaku pembantu dan pelaku peserta yang terdapat didalam suatu penyertaan

\section{Penanggulangan Secara Hukum Tindak Pidana Yang Dilakukan Oleh Seorang Dokter Dalam Bidang Hukum Kesehatan}

Mengingat banyak jenis-jenis tindak pidana pemalsuan surat, maka penulis menyadari betapa pentingnya pemahaman jenis-jenis tindak pidana pemalsuan surat, karena dengan memahaminya diharapkan tidak ada kesalahan dalam penjatuhan saksi yaitu dengan berpedoman sesuai dengan aturan yang termuat dalam KUHP, namun sebelum Penulis memaparkan jenis-jenis tindak pidana pemalsuan surat ini.

Delik formal atau delik dengan perumusan formal adalah delik yang dianggap telah selesai (voltooid) dengan dilakukannya suatu perbuatan yang dilarang, jadi delik formal adalah perbuatan yang sudah menjadi delik selesai (voltooid delict) dengan dilakukannya perbuatan. Salah satu Contohnya pada Pasal 362 KUHP tentang pencurian, dengan melakukan perbuatan "mengambil" maka perbuatan itu sudah menjadi delik selesai. Delik material atau delik dengan perumusan material adalah delik yang baru dianggap selesai (vooltooid) dengan timbulnya akibat yang dilarang (Maramis, 2012). Upaya penal merupakan penanggulangan suatu kejahatan dengan menggunakan hukum pidana yang didalamnya terdapat dua masalah sentral, yaitu perbuatan apa yang seharusnya dijadikan suatu tindak pidana dan sanksi apa yang sebaiknya digunakan atau dikenakan pada pelanggarKebijakan penanggulangan kejahatan dengan sarana non penal hanya meliputi penggunaan sarana social untuk memperbaiki kondisi-kondisi sosial tertentu, namun secara tidak langsung mempengaruhi upaya pencegahan terjadinya kejahatan (Http;//www.harianpilar.com diakses tanggal 23 september 2019). Upaya non penal dalam menanggulangi kasus malpraktek dapat dilaksanakan dengan cara preventif (pencegahan terjadi tindak pidana), yaitu dengan cara melakukan penyuluhan atau pun sosialisasi kepada tenaga kesehatan. Agar setiap tenaga kesehatan lebih berhati-hati lagi dalam melakukan tugasnya sebagai tenaga medis.

Upaya non penal dalam menanggulangi suatu kasus pemalsuan surat dapat dilaksanakan dengan cara preventif (pencegahan terjadi tindak pidana), yaitu dengan cara melakukan penyuluhan atau pun sosialisasi kepada tenaga kesehatan. Agar setiap tenaga kesehatan lebih berhati-hati lagi dalam melakukan tugasnya sebagai tenaga medis. Upaya penanggulangan terhadap kasus pemalsuan surat sebenarnya yang lebih berwenang adalah Tim dari kesehatan 
Juli Shara Pasaribu, Chistofe Daeli,Koko Valensio Situmeang, , \& Sonya Airini Batubara, Pertanggung Jawaban Hukum oleh Seorang Dokter yang Melakukan Tindak Pidana Pemalsuan Surat Keterangan Dokter

itu sendiri karena merekalah yang lebih paham terhadap apa yang mereka lakukan, apakah sudah sesuai dengan ilmu yang mereka pelajari atau tidak.

Menurut penulis sendiri upaya penanggulangan pemalsuan surat yang dilakukan merupakan upaya yang sesuai dengan ketentuan yang terkait. Upaya penanggulangan kejahatan non penal lebih bersifat tindakan pencegahan untuk terjadinya kejahatan, maka sasaran utamanya adalah menangani faktor-faktor penyebab terjadinya kejahatan. Faktor-faktor kondusif itu antara lain, berpusat pada masalah-masalah atau kondisi-kondisi yang secara langsung atau tidak langsung dapat menimbulkan atau menumbuh suburkan kejahatan

\section{SIMPULAN}

Etika sangat dipengaruhi oleh pandangan agama, pandangan hidup, kebudayaan, dan kekayaan yang hidup ditengah masyarakat, sehingga sangat sulit untuk menilainya. Seorang dokter wajib hanya memberikan surat keterangan dan pendapat yang telah diperiksa sendiri kebenarannya Dokter yang secara sadar membuat pemalsuan surat di atas sumpah dapat dipidana sesuai Pasal 242 ayat (1) KUHP, hukuman penjara selama-lamanya delapan tahun enam bulan bagi dokter yang melakukan pemalsuan surat. Dihukum orang yang mempergunakan surat keterangan palsu dari tabib tersebut seolah-olah tidak palsu. Di dalam Upaya penanggulangan agar tidak terjadi pemalsuan surat dapat dilakukan melalui 2 (dua) cara yaitu penal dan non penal

\section{DAFTAR PUSTAKA}

Aludin, (2008), Analisi Yuridis Terhadap Tindak Pidana Pemalsuan Surat Yang Dapat Mengakibatkan Kerugian Terhadap Orang Lain, Jurnal, 9(1).

Arif, B.N., (2008), Masalah Penegakan Hukum dan Kebijakan Hukum Pidana dalam Penanggulangan Kejahatan. Kencana, Jakarta.

Bambang, (2016),kriminologi dan masalah kejahatan suatu pengantar ringkas, Jakarta; Pustaka Azzam

Chazawi, A. (2011), Pelajaran hukum pidana bagian 1, Jakarta: Raja Grafindo

Chazawi, A. dan Ferdinan, A, (2016), Tindak Pidana Pemalsuan: Tindak Pidana yang Menyerang Kepentingan Hukum Terhadap Kepercayaan Masyarakat Mengenai Kebenaran Isi Tulisan dan Berita yang Disampaikan, Jakarta.

Chazawi, A., (2002), Kejahatan Mengenai Pemalsuan, Jakarta; PT. Raja Grafindo Persada

Ferdinan, A., (2016) Tindak Pidana Pemalsuan: Tindak Pidana yang Menyerang Kepentingan Hukum Terhadap Kepercayaan Masyarakat Mengenai Kebenaran Isi Tulisan dan Berita yang Disampaikan , Jakarta

Hunt, (1978), the sociologicl movement in law, London.

Jayanti, N, (2009), Penyelesaian Hukum dalam Malpraktek Kedokteran ,Yogyakarta: Pustaka Yustisia,, cet, ke-I.

Jusiven, (2000) analisis yuridis terhadap malpraktek yang dilakukan dokter, https://id.wikipedia.org/wiki/Pemalsuan diakses tanggal 27 september 2019

Kartanegara, S., (2017) Hukum Pidana II Delik-Delik Tertentu, Jakarta

Lasminar S, L., \& Isnaini, I. (2014). Kajian Hukum Terhadap Keterangan Ahli (Dokter) Dalam Pembuktian $\begin{array}{llll}\text { Kasus Penyalahgunaan Narkotika. JURNAL MERCATORIA, } & \text { 7(2), } & \text { 125-143. }\end{array}$ doi:https://doi.org/10.31289/mercatoria.v7i2.664

Marpaung, L., (2011),hukum pidana, Bandung;Citra Aditya,

Maramis, F., (2012), Hukum Pidana Umum dan Tertulis di Indonesia , Jakarta, PT Raja Grafindo Persada

Samidjo, (2012), metode penelitian Hukum, Jakarta; PT.Raja Grafindo

Santosa, W. (2016), Interprestasi Kerugian Dalam Tindak Pidana Pemalsuan Surat, Jurnal komisi yuridis Republik Indonesia, 3(5), Jakarta

Satoso, T. (2001), criminologi, Jakarta; Penerbit PT Raja Grafindo

Simons, D., (1992), Leerbook Van Her Nederlandsche Strafrecht, Diterjemahkan Oleh Panda Guritno, Soedarsono dan Hratono soerjopraknyo, Yogyakarta: Penerbit Yayasan Penerbit Gadjah Mada

Suharto, (2016), KUHP serta komentar-komentar lengkap pasal demi pasal, Bogor; politea

Syamsyudin, (2004), jenis-jenis pemalsuan surat, Bandung;PT Eresco

Http;//www.harianpilar.com diakses tanggal 23 september 2019

Http;//www.harianpilar.com diakses tanggal 23 september 2019

4. http://mahesainstitute.web.id/ojs2/index.php/jehss

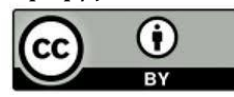


https://id.wikipedia.org/wiki/Pemalsuan diakses tanggal 27 september 2019

https://www.hukumonline.com/klinik/detail/ulasan/lt5812fd6ae0ce3/pidana-bagi-dokter-vang membuat-surat-keterangan-sakit-palsu/diakses tanggal 10 januari 2020

https://www.hukumonline.com/klinik/detail/ulasan/lt5812fd6ae0ce3/pidana-bagi-dokter-yangmembuat-surat-keterangan-sakit-palsu/

Kitab undang-undang hukum pidana

Kitab undang-undang hukum pidana

Kitab Undang-undang hukum pidana

Undang- undang No .4 Tahun 2011 Tentang Disiplin Profesional Dokter

Undang-undang No 1 Tahun 1946 tentang hukum pidana 